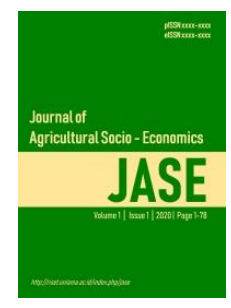

\title{
The Influence of Brand Image and Product Quality on Customer Loyalty in Petik Madu Lawang Agro tourism
}

\author{
Yoel Crhistony Gultom, Ana Arifatus Sa'diyah*, Ninin Khoirunnisa' \\ University of Tribhuwana Tunggadewi, Malang, Indonesia \\ *E-mail: ana.arifatus@unitri.ac.id
}

\begin{abstract}
This study aims to analyze the effect of brand image and product quality on customer loyalty in Petik Madu Lawang Agrotourism. This study uses primary data with sampling techniques using non-systematic sampling techniques, namely accidental sampling technique. The study was conducted for 2 months, and it was determined that there were 119 samples. The sample was analyzed using path analysis. The results of the analysis show that the variables of brand image and product quality have a significant effect on customer loyalty positively in Petik Madu Lawang Agrotourism.
\end{abstract}

Keywords: Agro-tourism, path analysis, honey

\section{INTRODUCTION}

Honey is a sweet liquid that has many properties. Honey is known as a drink that is good for health or beauty, so it is in great demand (Ajibola et al., 2012; Tola et al., 2017; Cardoso et al., 2017). Honey has been used by humans since 2,500 years ago. Honey is currently a commodity that is competitive in the business world (Faisal M. Sakri, 2015). The number of honey entrepreneurs in Indonesia has always increased from year to year. This condition causes honey entrepreneurs to be ready to face intense competition in the business world (Landstrom, H., 2007; (Rezaei. Moghaddam, K., \& Izadi, H., 2019). Business competition causes companies to be required to satisfy consumer needs by producing goods or products according to what consumers want. In today's business competition, companies must provide an advantage to be able to compete with other companies that produce the same product (Rangkuti, F., 2013).

Increasingly tighter competition, where more and more producers are involved in fulfilling the needs and desires of consumers, causing each company to place an orientation on customer satisfaction as the main goal. (Guntur, 2010; Park, C. W., Jaworski, B. J., \& MacInnis, D. J., 1986). Today many companies or organizations have recognized the importance of being customer oriented in all marketing activities. Companies compete competitively in terms of creating and maintaining loyal customers, namely by brand image and product quality (Alfred 2013; Shankar, V., Urban, G. L., \& Sultan, F., 2002; Javalgi, R. R. G., Martin, C. L., \& Young, R. B., 2006).

Brands can provide all kinds of directions for customers. Brands can provide a description of the business, culture, appearance, work processes, and also trademarks. Once a product is accepted by consumers, the marketing of products and services will be easier to accept. When almost all companies offer products that are almost uniform, then the quality, identity, and brand of the company are very important to differentiate it from other products (Susanti, N. P. H., \& Wardana, I. M., 2014; Evawati 2012).

Currently, competition is increasing among brands operating in the market. Only products that have a strong brand image are still able to compete and dominate the market (Wang, H., Wei, Y., \& Yu, C., 2008; Maryati, 2014; Steenkamp, J. B. E., \& Dekimpe, M. G., 1997). The stronger the brand image in the hearts of consumers, the stronger the confidence that consumers have to remain loyal and loyal to the products they buy. That way the company will get fixed profits from time to time. A company that 
has a product with a favorable brand image will definitely gain a better position in the market while maintaining its competitive advantage and increasing the number of market shares. Not only brand image, product quality also affects customer satisfaction to be loyal to a product.

Brand image describes the quality of the products the company produces. Companies must pay attention to the quality of the products produced. Quality is one of the basic things of customer satisfaction that makes consumers loyal, but it is one of the keys to the company's success in competing. Quality is a measure of all companies to show consumers that they are able to provide high quality expectations. The higher the quality of the products the company produces, the more loyalty it will be for customers (Angelova, B., \& Zekiri, J., 2011; He, H., \& Li, Y., 2011; Delgado-Ballester, E., \& Munuera-Alemán, J. L., 2001; Yuen, E. F., \& Chan, S. S., 2010).

Product quality has a close relationship with customer satisfaction. Quality will encourage consumers to forge a close relationship with the company (M Aziz, 2014; Pambudi, T. S., 2013; Day, G. S., 2000; Wong, A., \& Sohal, A. S., 2006). Dalam jangka panjang hubungan ini memungkinkan sebuah perusahaan dapat memahami keinginan, kebutuhan dan harapan konsumen. Maka pada akhirnya akan menciptakan loyalitas pelanggan kepada perusahaan yang menurut mereka telah memberikan kualitas yang sangat memuaskan (Tjahyadi, R. A., 2006; Kusumawati, A., 2011). This study aims to analyze the effect of brand image and product quality on customer loyalty in Petik Madu Lawang Agrotourism.

\section{METHODS}

The research was conducted in Lawang Honey Petik Agrotourism, Malang Regency. The study used all consumers in the honey-picking agro-tourism of Lawang District as a population, so the population size was unknown. The sampling technique used non-systematic sampling technique, namely accidental sampling technique. According to Sugiyono (2009); Ferdinand (2011) Accidental sampling is a sampling technique based on chance, that is, consumers who accidentally meet the researcher can be used as a sample, if the person who happens to be considered a suitable data source.

The study was conducted for 2 months, and it was determined that there were 119 samples. The samples were analyzed using path analysis, namely, an analytical technique developed from multiple regression analysis, with the main subject being the correlating variables. This model aims to determine the direct and indirect effects on predetermined variables. When described, the schematic of the path analysis is as follows:

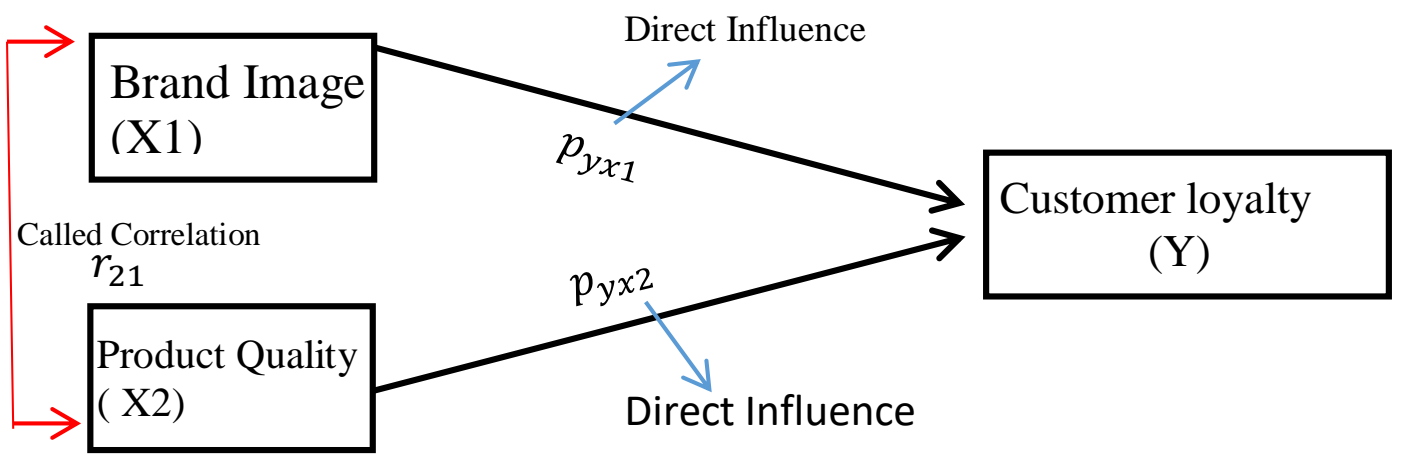

Figure 1. Analysis Results of Path Correlation Model

According to Sarwono (2011) path analysis is defined as an analytical technique used to analyze the cause-and-effect relationship between variables arranged on a temporary order by using the path coefficient as a value measure in determining the magnitude of the influence of the independent (exogenous) variable on the dependent (endogenous) variable. The exogenous variable is a variable for which there is no explicit cause or in the diagram there are no arrows pointing towards it. If the exogenous variables are correlated, the correlation is indicated by a double arrow connecting the two variables. endogenous variable is a variable which includes all intermediate and direct variables. This variable has arrows leading to it. 


\section{RESULT AND DISCUSSION}

The results of the path analysis are presented in table 1. Statistically, brand image and product quality have an effect on customer satisfaction (Table 1). The value of Adjusted R square (R2) is 0.672 which means that the variables of brand image, product quality, service quality and customer satisfaction are able to explain customer loyalty by $67.2 \%$, while the remaining $32.8 \%$ is explained by other variables not examined in this study.

Tabel 1. The results of the Part Analysis

\begin{tabular}{lcccl}
\hline \multicolumn{1}{c}{ Variable } & $\begin{array}{c}\text { Standardized } \\
\text { Coefficients }\end{array}$ & $\mathrm{t}$ hitung & Sig. & Explanation \\
\hline Brand Image & 0.328 & 3.585 & 0.000 & Signifikan \\
\hline Product Quality & 0.419 & 4.575 & 0.000 & Signifikan \\
\hline $\mathrm{R}^{2}=0.468$ & & & & \\
\hline
\end{tabular}

primary data, processed in 2019

$\mathrm{X} 1$ : Brand Image Variable (X1)

X2: Product Quality (X2)

Dependent Variable: Customsr Loyalty (Y)

Table 1 illustrates the effect of brand image and product quality on customer loyalty in the Lawang Honey Petik Agrotourism which is statistically significant. Based on the $\mathrm{t}$ test the brand image variable (X1) has a value of t count 3.585 at sig. $t$ is 0.000 , which means the path analysis coefficient is significant. Thus, the brand image variable (X1) has a significant effect on customer loyalty (Y). There is a positive effect of brand image on customer loyalty at Petik Madu Lawang Agro. While the product quality variable (X2) has a value of $t$ count 4.575 in sig. $t$ is 0.000 , which means the path analysis coefficient is significant. Thus the product quality variable (X2) has a significant effect on customer loyalty (Y). There is a positive effect of product quality on customer loyalty at Petik Madu Lawang Agro.

The analysis results show that the path coefficient ( $\beta Y$.X1) of Brand Image (X1) to Customer Loyalty (Y) is 0.328 and the path coefficient ( $\beta Y$.X2) of Product Quality (X2) to Customer Loyalty (Y) is 0.419 . The coefficient of determination (contribution) $\mathrm{X} 1$ and $\mathrm{X} 2$ simultaneously to $\mathrm{Y}$ is 0.468 and the coefficient $\varepsilon 1$ is:

$\varepsilon 1=\sqrt{ } 1-0.468=\sqrt{ } 0.532=0.73$

Thus the path diagram is obtained as follows:

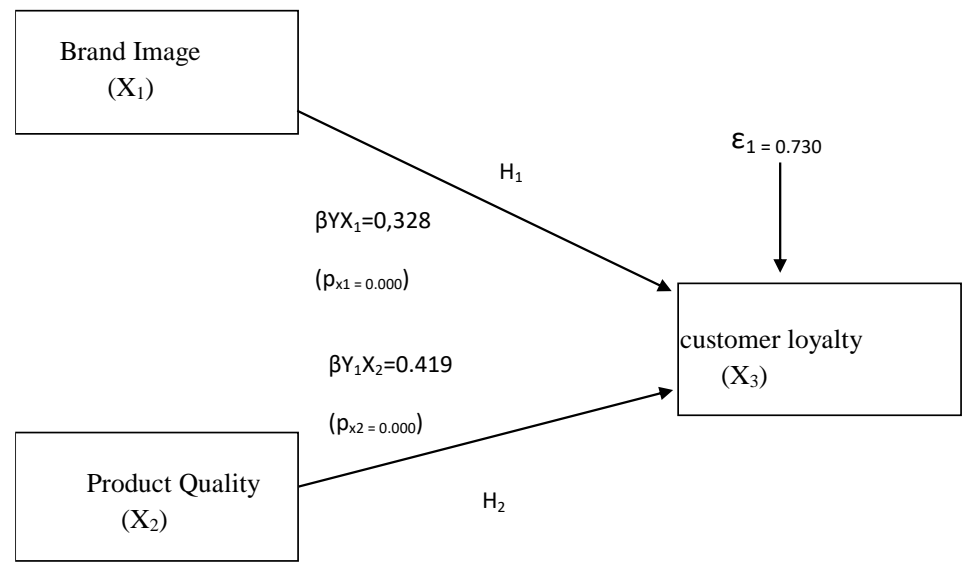

Figure 2. Result of Part Diagram X1 and X2 to Y

\section{CONCLUSION}

The variables of brand image and product quality have a significant effect on customer loyalty positively in Petik Madu Lawang Agrotourism. Efforts are needed from the management of Petik Madu Lawang 
Agro tourism to continue to improve the brand image and product quality so that customer loyalty will be higher.

\section{REFERENCES}

Ajibola, A., Chamunorwa, J. P., \& Erlwanger, K. H. (2012). Nutraceutical values of natural honey and its contribution to human health and wealth. Nutrition and Metabolism, 9, 1-12. https://doi.org/10.1186/1743-7075-9-61

Angelova, B., \& Zekiri, J. (2011). Measuring customer satisfaction with service quality using American Customer Satisfaction Model (ACSI Model). International journal of academic research in business and social sciences, 1(3), 232.

Day, G. S. (2000). Capabilities for forging customer relationships (No. 118). Cambridge, MA: Marketing Science Institute.

Delgado-Ballester, E., \& Munuera-Alemán, J. L. (2001). Brand trust in the context of consumer loyalty. European Journal of marketing.

He, H., \& Li, Y. (2011). CSR and service brand: The mediating effect of brand identification and moderating effect of service quality. Journal of Business Ethics, 100(4), 673-688.

Javalgi, R. R. G., Martin, C. L., \& Young, R. B. (2006). Marketing research, market orientation and customer relationship management: a framework and implications for service providers. Journal of Services Marketing

Kusumawati, A. (2011). Analisis Pengaruh Experiential Marketing Terhadap Kepuasan Dan Loyalitas Pelanggan: Kasus Hypermart Malang Town Square (Matos) Analysing the Influence of Experiential Marketing on Customer Satisfaction and Loyalty: the Case of Hypermart Malang Town Square. Jurnal Manajemen Pemasaran Modern, 75-81.

Landstrom, H. (2007). Pioneers in entrepreneurship and small business research (Vol. 8). Springer Science \& Business Media.

Pambudi, T. S. (2013). Riding the Wave-Strategi Andal Menaklukkan Industri Software. Elex Media Komputindo.

Park, C. W., Jaworski, B. J., \& MacInnis, D. J. (1986). Strategic brand concept-image management. Journal of marketing, 50(4), 135-145.

Rangkuti, F. (2013). Strategi promosi yang kreatif dan analisis kasus. Gramedia Pustaka Utama

Rezaei-Moghaddam, K., \& Izadi, H. (2019). Entrepreneurship in small agricultural quick-impact enterprises in Iran: Development of an index, effective factors and obstacles. Journal of Global Entrepreneurship Research, 9(1), 17.

Sakri, F. M. (2015). Madu dan khasiatnya. Yogyakarta: Dinadra Pustaka Indonesia.

Shankar, V., Urban, G. L., \& Sultan, F. (2002). Online trust: a stakeholder perspective, concepts, implications, and future directions. The Journal of strategic information systems, 11(3-4), 325344.

Steenkamp, J. B. E., \& Dekimpe, M. G. (1997). The increasing power of store brands: building loyalty and market share. Long range planning, 30(6), 917-930.

Tjahyadi, R. A. (2006). Brand Trust dalam Konteks Loyalitas Merek: Peran Karakteristik Merek, Krakteristik Perusahaan, dan Karakteristik Hubungan Pelanggan-Merek. Jurnal Manajemen Maranatha, 6(1), 65-78.

Tola, N., Haile, G., Mekonnen, N., \& Furgassa, W. (2017). Negesa Tola, Geremew Haile Negesse Mekonnen and Walkite Furgassa. Review on Medicinal and Nutritional Value of Bee's Honey: Senior Seminar on Animal Health. Biomedicine and Nursing, 3(1). https://doi.org/10.7537/marsbnj030117.08

Wang, H., Wei, Y., \& Yu, C. (2008). Global brand equity model: combining customer-based with product-market outcome approaches. Journal of Product \& Brand Management.

Wong, A., \& Sohal, A. S. (2006). Understanding the quality of relationships in consumer services. International Journal of Quality \& Reliability Management.

Yoirish, N. (2001). Curative properties of honey and bee venom. The Minerva Group, Inc..

Yuen, E. F., \& Chan, S. S. (2010). The effect of retail service quality and product quality on customer loyalty. Journal of Database Marketing \& Customer Strategy Management, 17(3-4), 222-240. 